Research, part of a Special Feature on Do we need new management paradigms to achieve sustainability in tropical forests?

\title{
Wildlife Conservation in Bornean Timber Concessions
}

\author{
$\underline{\text { Erik Meijaard }}^{1}, \underline{\text { Douglas Sheil }}^{2}, \underline{\text { Robert Nasi }}^{3}$, and $\underline{\text { Scott A. Stanley }}^{1}$
}

\begin{abstract}
Based on an extensive review of the literature, and broad consultation with experts, we have assessed the sensitivity of Bornean vertebrates to the direct and indirect effects of timber harvest. Wellimplemented selective logging has a relatively limited direct impact on wildlife populations: few species appear quite sensitive, some benefit, some decline. However, current management practices in Indonesian Borneo generally cause a decline in wildlife populations. Guidelines for sustainable forest management are primarily focused on trees, with few specific recommendations on how to sustainably manage wildlife populations in timber concessions. Based on our findings, we provide extensive wildlife management guidelines, pointing out the importance of maintaining understory vegetation and large trees for fruit, seed, dead wood, and tree hollow production, limiting canopy gaps, and reducing hunting and wildlife trade in concessions. In addition, we provide specific management advice on high priority species of Bornean vertebrates.
\end{abstract}

Key Words: Asia; biodiversity; Borneo; disturbance; hunting; sustainable forest management.

\section{INTRODUCTION}

There is an increasing awareness that wildlife species in Indonesian Borneo need forests that are managed for sustainable timber extraction if they are to survive in the long term (Colón 1999, Lammertink 2004b, Sheil et al. 2004). In the past few decades, conservation efforts have focused strictly on protected areas, but recent insights have suggested that these reserves are insufficient to protect rare, threatened species. Not only is the protected area network fragmented (Jepson et al. 2002), but forests are also disappearing even within these protected areas (Fuller et al. 2003, Curran et al. 2004).

Kalimantan's protected area network is failing for various ecological, socioeconomic, and political reasons (Kramer et al. 1997, Rijksen and Meijaard 1999, Jepson et al. 2001, 2002). Ineffective management, however, is a dominant factor. Management, if any, is directed from regional or national offices, but without adequate on-theground staff to provide even basic safeguards, many protected areas remain paper parks (cf., Bruner et al. 2001, Rodriguez and Rodriguez-Clark 2001).
Poor political support for active conservation management is a global problem that is only slowly improving. Thus, conservation remains underfunded (e.g., Balmford and Whitten 2003), and tax systems providing financial compensation for using environmental services remain undeveloped.

Direct economic benefits such as timber production provide an incentive to maintain forests and a way to generate conservation benefits, especially when various economic and political forces are encouraging improved management practices. This, and the fact that forest loss threatens both conservation interests and timber production explains why tropical production forestry and conservation are increasingly finding common ground. Whether production forestry has the potential to halt forest decline, or to otherwise benefit conservation, is disputed (Bowles et al. 1998, Lugo 1999, Putz et al. 2000), but we wish to emphasize the pragmatic ecological basis for involving timber concessions in wildlife conservation.

Many Bornean wildlife species persist at only slightly altered densities in selectively harvested forests, and well-managed production forests can

\footnotetext{
${ }^{1}$ The Nature Conservancy-East Kalimantan, ${ }^{2}$ Center for International Forestry Research, ${ }^{3}$ Centre de coopération internationale en recherche agronomique
} 
provide adequate habitat for most species (Meijaard et al. 2005). Still, little is known about how different management approaches affect Bornean wildlife, and even less about how wildlife conservation might be balanced with commercial production benefits. Here we report on this issue, based on a literature review of Bornean wildlife and logging (Meijaard at al. 2005). We justify and outline practical recommendations for improved forest management that goes beyond current standards.

Some terms require definition. In Indonesia, as in most tropical countries, logging is selective: only commercial species over a set diameter limit, i.e., usually $>50 \mathrm{~cm} \mathrm{dbh}$, are removed. Various management stages are followed to avoid excessive damage to the remaining forest, starting with harvest planning, road and skid trail design, and tree felling procedures commonly referred to as reduced impact logging (RIL).

\section{METHODS}

We compiled and analysed data sets on how production forestry affects Bornean wildlife. We did this by reviewing all available published and unpublished literature on Bornean wildlife species, including mammals, bird, reptiles, and amphibians, and consulting widely with local and international experts. We analysed 282 publications derived from Borneo-based studies (Meijaard et al. 2005, Meijaard and Sheil, unpublished manuscript, Meijaard et al., unpublished manuscript), and a similar number of relevant publications based on research elsewhere in Southeast Asia (Meijaard et al. 2005). We selected certain species and assessed their tolerance to logging, i.e., both the direct impacts and related effects that often follow such as hunting and forest fragmentation. We provided an overview of the sensitivity of Bornean wildlife to logging, including common traits among species that are either negatively or positively affected (Meijaard et al., unpublished manuscript). On this basis, the general ecological effects of productive forestry and different wildlife management options could be examined, and recommendations could be developed to improve forest management. As part of this process we considered species-specific habitat requirements, allowing us to provide particular management recommendations to protect these forest attributes. An overview of the process can be found in Sheil and Meijaard (2005).

\section{ASSESSMENT OF SPECIES' TOLERANCE TO LOGGING}

\section{General patterns}

Our review indicates that of the 64 mammal and bird species investigated in detail, $23 \%$ increased by $>20 \%$ in density following logging, $46 \%$ were relatively neutral, i.e., <20\% changed, and $42 \%$ declined significantly, i.e., $>0 \%$ decline. Our literature review reveals that none of the species studied became locally extinct due to logging, at least not within the investigation period, which was typically $<3$ yr. We did not choose our test species objectively, but depended instead on the information available; thus, the choice was that of the original researchers. Each study has its specific context, limitations, and associated uncertainties, which makes generalizations somewhat problematic. Still, the percentages give some indication of how logging affects Bornean vertebrate fauna, with probably less than half of the species showing a clearly negative impact. We do not want to downplay the impact of timber harvesting on wildlife, and recognize that methodological uncertainties remain, but we do point out that the negative effects are less than commonly assumed. General and specific patterns in tolerance provide a basis for developing wildlife-friendly guidelines for forest management.

Our analyses identify patterns among species with different logging tolerance levels. Intolerant mammals tend to have narrow ecological niches, and many have strictly frugivorous, carnivorous, and insectivorous feeding habits. They appear to be specialized to live in particular forest strata, especially ground or upper canopy levels, rather than ranging through all levels. In contrast, loggingtolerant mammals are herbivorous or more omnivorous. Many of these species live in the lower vegetation strata, although some are found at all levels. Birds show similar relationships between widths of ecological niches and tolerance (e.g., Lambert and Collar 2002), with canopy nectarivores and generalist frugivore/insectivores increasing after logging (Johns 1989, 1996, Lambert 1992, Zakaria 1994). Specialized insectivores in the lower vegetation strata, on the other hand, appear to have a low tolerance to logging-related disturbances. Amphibians seem to cope relatively well with the effects of reduced impact logging according to data from Sabah, suggesting that such methods may result in greater diversity than in unlogged forests. 
However, note that the long-term effects of an increase in nonforest species on forest species is presently unknown (Wong 2006a,b, in press). Conventional logging, especially where it leads to a much reduced leaf litter layer, leads to sometimessignificant declines in amphibian diversity and abundance (Iskandar 1999, Wong 2006a, in press). Finally, our review suggests that a few fish species such as the bottom-dwelling Gastromyzon spp. and Garra borneensis, and near-bottom dwelling herbivorous or frugivorous Lobocheilos bo, Osteochilus chinni, and Tor spp. are sensitive to production forestry (Rachmatika et al. 2004). However, even these species can quickly recolonize rivers once logging ceases (Martin-Smith 1998).

As opposed to the direct effects of timber extraction, fragmenting large contiguous forests into much smaller blocks seems to affect a much broader range of species. This is the case at least for omnivorous, insectivorous, frugivorous, and nectarivorous birds, and virtually all species negatively affected by logging, but note that some birds benefit from logging and fragmentation, especially generalist, nonforest species (Lambert and Collar 2002). No detailed studies have been conducted on how fragmentation affects Sundaic mammals, although a study by Brook et al. (2003) linked mammal extinctions in Singapore to dwindling habitat. Roads in concessions also notably fragment the forest, but many species can easily cross these roads.

Finally, hunting appears to be a major factor determining wildlife densities in selectively logged forests, especially for specifically targeted species. This has been extensively documented in Sarawak, Malaysian Borneo, where a clear link exists between timber harvesting and hunting (e.g., Bennett and Gumal 2001). The effect of hunting has also been reported from Kalimantan (Nijman 2004, 2005, Marshall et al. 2006) and is inferred from first-hand observation in areas with high and low hunting pressures (E. Meijaard, personal observation). Hunting generally affects those species most sought after for food or trade such as pigs, deer, muntjacs, monkeys, porcupines, pheasants, hornbills, and turtles, although snaring kills many nontarget species as well.

\section{Species-specific patterns}

Besides the general patterns in species' tolerances, logging affects particular species in specific ways. For instance, logging in Borneo primarily targets dipterocarps, and it would be expected that vertebrates specifically depending on these and other commercial timber species would be disproportionately affected. Few vertebrates probably have an obligatory relationship with dipterocarps, although it is clear that seed eaters such as bearded pigs (Sus barbatus), Muntiacus species, porcupines, certain squirrels, and some hornbills use these trees at least some of the time. By retaining very large dipterocarp trees, forest regeneration can be enhanced through a greater production of seeds, beyond what seed eaters consume. Such large trees also contribute disproportionately to the total amount of dead wood available in a forest (Grove 2001), and dead wood provides a key habitat element for many Bornean species (Bernard 2004).

Large-stemmed trees provide many species with hollows for nesting and storing food. The helmeted hornbill (Rhinoplax vigil), for instance, appears to prefer large dipterocarp species such as Hopea and Shorea spp. with a dbh $>105 \mathrm{~cm}$ for nesting (Thiensongrusamee, personal communication). The distribution and determinants of tree hollows have been little studied, but hollows are more likely to occur in large-stemmed, mostly dbh $>60 \mathrm{~cm}$, species with relatively light timber and susceptible to heart rot. Initially, after limited timber removal, large and damaged trees may be prone to forming cavities, but ultimately this may change if larger trees are removed, perhaps over several cutting cycles.

Some trees, most notably figs (Ficus spp.), are especially important for wildlife as stands provide fruit throughout the year (Jordano 1983, Lambert 1989a,b,c, 1990, 1991, Heydon and Bulloh 1997, O'Brien 1998, Kinnaird et al. 1999), and fulfill vital nutritional needs such as the calcium needed by vertebrates living on otherwise mineral-poor diets (see O'Brien et al. 1998). Depending on the species, fig trees per se do not usually fruit all year and so a large area with sufficient trees is needed for a yearround supply. Several studies have reported a decline in fig densities following logging (Johns 1983, Leighton and Leighton 1983, Lambert 1990, Heydon and Bulloh 1997), indicating that logging lowers the forest's carrying capacity for species that 
feed primarily on these fruits. Wild banana (Musa spp.) is another potential year-round fruit source, but its importance for wildlife remains unstudied. These pioneer plants are often common in disturbed areas and may reduce the impact of logging on frugivores such as various civets and macaques.

Many species also depend on particular structures for perching, foraging, breeding, or resting. Woodpeckers have been studied very well in this respect, and foraging substrates for most woodpecker species are well known (Styring 2002, Styring and Ickes 2003, Lammertink 2004b). However, we have limited knowledge of the structural requirements for most other species. Logging affects the three-dimensional structure of a forest in many ways, and we cannot generalize here about the effects on any particular species. Some species such as deer or certain frogs and toads, can benefit from the creation of gaps, which could in turn provide extra food for carnivores. Other species such as the interior forest bats Hipposideros spp. and Rhinolophus spp. might fail to find food in gaps (see Kingston et al. 2003). Some species, including some small rodents, may benefit from the denser, more complex understory conditions that follow logging (Bernard 2004), whereas the forest owls Otus rufescens and frogmouths Batrachostomus spp. seem to require the orderly and open structure of primary forests. Again, the more adaptable a species is in its behavior, the more likely it can cope with the effect of logging.

\section{How can forests be managed to ensure higher compatibility between wildlife conservation and timber harvesting?}

What are the implications of our findings for timber concession management? Our data show that although many species experience density declines following logging, most or all of them survive the initial effects. Unfortunately, many of the most adversely affected species are also the most endangered according to the IUCN (2003) Red List criteria (Meijaard and Sheil, unpublished manuscript). It would be beyond the ability of concession managers to protect all the ecological needs of the vertebrate specialists most affected by timber harvesting, but some simple improvements could go a long way toward reducing impacts on the most threatened species. Wildlife-friendly timber management objectives could include reducing overall impacts caused by road building, gap creation, and the slashing of climbers and ground vegetation, combined with safeguarding no-logging and no-hunting zones. Experiments in East Kalimantan have demonstrated that logging damage can only be significantly reduced under a moderate felling intensity of 8-9 trees/ha, but 10-11 trees/ha is common practice (Sist 2001, Sist et al. 2003b). Limiting harvesting to trees $>100 \mathrm{~cm}$ dbh should not significantly constrain production (Sist et al. $2003 a$ ), and it would provide ecologically important old-growth stems while reducing damage. Lighter machinery could also be used if loggers would avoid removing the very largest stems.

Below we suggest some wildlife-friendly measures specifically designed for Borneo's production forests. Many steps must be taken to achieve full compatibility between wildlife conservation and tropical forestry, but we believe that, although adding to the initial costs, the long-term economic benefits are considerable.

\section{Species-specific issues}

So far, we have not incorporated specific advice in our recommendations on how to protect important local wildlife species. "Importance" is difficult to define and depends on the stakeholders' perspectives. Still, one approach is to consider national and international protection and conservation status, and the degree of local use and cultural significance, and its range. Thus, we have identified the highest priority species using the IUCN status of Bornean species (IUCN 2003), their protection status under Indonesian law (Noerdjito and Maryanto 2001), and their importance to local communities, based on several published data sets (after Puri 1997, after Wadley et al. 1997, Puri 2001, Sheil et al. 2002). We realize that this list does not include all priority species, but it provides guidance for what we consider to be the most important conservation targets, while addressing local community requirements.

\section{Primates}

Hunting is the main threat to species in timber concessions, especially Bornean gibbon (Hylobates muelleri), Hose's leaf monkey (Presbytis hosei), white-fronted leaf monkey $(P$. frontata), slow loris (Nycticebus coucang), pig-tailed macaque (Macaca nemestrina), and Bornean orangutan (Pongo pygmaeus) (Wadley et al. 1997, Nijman 2004, 
Marshall et al. 2006), but extensive clearing, and canopy and interior forest disturbance/loss also take their toll. Because of their protected status, we strongly recommend a complete prohibition on hunting these species in concession areas. The only exception is $M$. nemestrina, which is not protected; for this species we recommend setting quotas in designated hunting zones, and monitoring the impact on the population. Self-monitoring of hunting by communities, even in protected areas, is increasingly successful in controlling the impacts (Noss et al. 2004). Because orangutans attract global interest, a concessionaire could benefit from having this species in their concession. If fruit trees are retained and no hunting occurs, a surviving orangutan population could be of considerable public relations value.

\section{Ungulates}

Ungulates include the rare Bornean banteng (Bos javanicus), sambar (Cervus unicolor), and muntjaks (Muntiacus spp.). All of these species are protected, although the hunting pressure on them is high (Puri 1994, Bennett et al. 2000). These species, except for the Bornean endemic Muntiacus atherodes, should benefit from the more open conditions created following road building and timber extraction (see Meijaard et al. 2005). They are also attracted to grazing the herbaceous vegetation common on roadsides. However, this makes them very vulnerable to hunting and we recommend that all hunting of these animals be prohibited, unless a legal agreement can be obtained from the Ministry of Forestry allowing an annual take-off quota. Other ungulates, like mouse-deer (Tragulus spp.) and pigs (Sus barbatus), are even more commonly hunted, but generally appear to survive in timber concessions as long as forests are well managed, thus securing sufficient food resources. Important habitat features like salt licks and large wallows should be mapped and protected from disturbance within exclusion zones.

\section{Civets}

Logging appears to negatively affect some of these species, including the carnivorous banded palm civet (Hemigalus derbyanus) and other nongeneralist feeders (see Meijaard et al. 2005). Still, we regularly encounter most lowland civet species, apart from banded linsang (Prionodon linsang) and binturong (Arctictis binturong), in well-managed forestry concessions. This suggests that the more common species do not require special management attention. The banded linsang and binturong are protected in Indonesia, and all hunting should be prohibited. Because civets are occasionally hunted for food, and because they are considered live stock pets, we recommend including civets in a hunting monitoring program.

\section{Cats}

The impact of logging on tropical cats remains unstudied. From our personal observations, timber extraction alone does not appear to significantly affect cats. We recognize, though, that this observation may be biased by frequent cat sightings along logging roads, to which they may be attracted by good hunting conditions. Also, cats are more easily seen along roads. Hunters target cats for their pelts, despite their protected status, and hunting control in concessions is important. Including cats in a simple monitoring program, for instance by noting all records on logging roads, enables the concession holder to monitor temporal and spatial changes in populations. Cats are also popular, and having reliable sighting opportunities may provide incentives for ecotourism. Establishing where the species occurs in a logging concession would be a primary objective. Sightings and signs should be reported to biologist monitors or concession managers.

\section{Malayan sun bear}

Timber extraction seems to have a generally negative impact on sun bears, although they can survive at high densities in lightly disturbed forests (Augeri 2004, Meijaard et al. 2005). Hunting associated with logging has significant impacts on populations (Meijaard 1999). The species is protected in Indonesia, but targeted by hunters for pelts, teeth, claws, meat, and gall bladder, so hunting should be prohibited in timber concessions.

\section{Squirrels}

Squirrels vary considerably in the extent to which they cope with logging (see Meijaard et al. 2005). Some species from the Callosciurus group seem well adapted to disturbed environments, whereas specialist frugivore or insectivore feeders like some Sundasciurus, Ratufa, and Rhinosciurus species decline in logged forests. Only Lariscus insignis is protected in Indonesia, although hunting does not seem to be a major threat. We do not provide any 
recommendations for species-specific management, apart from a hunting ban on protected species.

\section{Bats}

Bats are pollinators and seed dispersers of considerable economic and ecological importance. Their tolerance of timber extraction depends on their ecology. Bats feeding in open areas are favored, whereas small forest bats disappear rapidly after logging. Most species remain poorly known, and no bats are protected in Indonesia. Therefore, we do not provide any recommendations for species-specific management. A generally positive measure is to protect roosting sites such as naturally fallen trees, caves, and rock faces.

\section{Hornbills}

Hornbills, especially helmeted hornbill (Buceros vigil), rhinoceros hornbill (B. rhinoceros), and black hornbill (Anthracoceros malayanus) are primarily affected by hunting, loss of breeding space, and loss of food sources (Bennett et al. 1997, Bennett and Gumal 2001). Because these birds are protected by Indonesian law, we recommend prohibiting all hunting in timber concessions. We also recommend retaining very large trees and fruit trees. If hornbill nests are found in trees selected for logging, this means the tree is certainly hollow and it should therefore be left standing. If a nesting tree needs to be cut for other reasons such as road building, this should be done after young birds have left the nest. Hornbill nesting can occur throughout the year, but in Borneo it seems to be concentrated between January and April (see Meijaard et al. 2005 for an overview). The nesting cycle is, at most, $130 \mathrm{~d}$, and we recommend that if a tree with an active nest needs to be cut, this should be planned some three mo beforehand, allowing the birds time to leave.

\section{Pheasants}

Bulwer's pheasant (Lobiophasis bulweri), crestless fireback (Lophura erythrophthalma) and great argus (Argusianus argus) are primarily affected by hunting, loss of food sources such as fallen fruit and invertebrates in leaf litter, and human disturbance (see Meijaard et al. 2005). Counteraction is best achieved by setting aside sufficiently large areas in which populations of these birds are protected. If areas in concessions are protected for pheasants, the areas should be sufficiently large and include undisturbed sections of hill forest and alluvial valleys.
Storm's stork (Ciconia stormi)

Storm's stork is an endangered species with an estimated global population $<1000$ (BirdLife International 2001). It is primarily restricted to unlogged or lightly logged lowland forests with very little human disturbance. If this species occurs in a concession, we recommend that the concessionaire contact local NGOs or research institutions for specific advice on how to manage these birds. It is protected and so no hunting or other detrimental activities are allowed.

Straw-headed bulbul (Pycnonotus zeylanicus)

Straw-headed bulbul is much sought after as a cage bird (Holden, 1997 in BirdLife International 2001). Populations are in severe decline and "have been virtually exterminated as a wild bird" in Indonesia (Holmes, 1995 in BirdLife International 2001). It is not protected in Indonesia, but this species needs active protection: collection in concessions must be forbidden.

Great slaty woodpecker (Mulleripicus pulverulentus)

Great slaty woodpecker is found in level lowland forests; its density is reduced $>80 \%$ in logged forest compared with primary forests (Lammertink $2004 a$ ). It requires large-diameter live trees to forage for stingless bee, ant, and termite nests located in natural cavities in large branches and tree trunks. Retaining large-diameter live trees, dipterocarps and other tree species in level lowland forests will reduce severe declines in woodpeckers after logging.

\section{Turtles}

Over-collection threatens the Malayan flat-shelled turtle (Notochelys platynota), brown giant tortoise (Manouria emys), and possibly the common softshell turtle (Amyda cartilaginea). Although listed as seriously threatened with extinction (IUCN 2003), these species are not protected by Indonesian law. A primary objective should be to establish densities and numbers, and work toward a sustainable level of harvesting.

\section{Carps, Tor spp. and Pangasius spp.}

These species require clear water, are dependent on forest vegetation, easily caught, have a relatively low reproductive rate, and are keenly sought. They are migratory, using upstream spawning areas. 
Pangasius, especially, forms seasonal aggregations when breeding, which makes overfishing easy. Tor spp. are herbivores/frugivores and are believed to be associated with Dipterocarpus or Ficus trees, which grow along the banks, and with algae growing in clear water on unsilted river beds. A primary objective should be to establish densities and numbers for the various species and work toward a sustainable harvesting level. Furthermore, careful stream management should ensure clear streams and pools so that logging does not severely affect carp populations (Rachmatika et al. 2004).

In addition to our recommendations, concessions may choose to focus on conserving particular local priority species. They may want to boost ungulate populations to supply sufficient protein to concession workers and local communities, while boosting key carnivore species such as the Clouded Leopard. This would require creating grazing zones that attract ungulates, while developing and enforcing sustainable harvest levels. Another concession may be more interested in local orangutan populations, but note that concessionaires are obliged to protect the habitat of all protected species (see Ministry of Forestry 1990). In this case, orangutan numbers could be boosted by ensuring that enough soft-pulp fruit trees remain and that poaching does not occur.

\section{CONCLUSION}

We initiated this research because we realized that sustainable forestry criteria are primarily focused on maintaining timber production, with a secondary focus on institutional issues and forestry's socioeconomic aspects. Few practical recommendations exist on how to deal with wildlife issues. Surprisingly, despite decades of zoological research on Borneo, almost none of this research is reflected in best forestry practice (for a discussion see Meijaard and Sheil, unpublished manuscript). Our review indicates there are ways that sustainable management can be seen as contributing to conservation rather than as a threat. Forestry concessions are an essential part of the total forest area needed to guarantee the long-term survival of Borneo's wildlife.

Based on our review, we sought recommendations and guidelines that would increase the compatibility between forestry and wildlife conservation. Although we were struck by the lack of detailed recommendations (Meijaard and Sheil, unpublished manuscript), we were convinced that many improvements could and should be included in concession practices. If willing partners can be found in the logging industry, implementing our recommendations could lead to considerable conservation benefits. These successes should show other forestry concessions and government that wildlife conservation and forestry could be compatible in the Southeast Asian tropics.

Responses to this article can be read online at:

http://www.ecologyandsociety.org/vol11/iss 1/art47/responses/

\section{Acknowledgments:}

This study was carried out as a part of the project on Forest, Science and Sustainability: Bulungan (Malinau) Model Forest, PD12/97 Rev. 1 (F) funded by the International Tropical Timber Organization (ITTO) and implemented by the Center for International Forestry Research (CIFOR), the Forest Research and Development Agency (FORDA) of the Ministry of Forestry of Indonesia. It involved collaboration between the Center for International Forest Research (CIFOR) and the Wildlife Conservation Society, Indonesia Program (WCS-IP). Many thanks to Claire Miller and anonymous reviewers for help in improving previous versions of this text.

\section{LITERATURE CITED}

Augeri, D. 2004. Effects of disturbance on Malayan Sun Bear habitat use. Paper presented at the International Conference on Conservation Science (Cambridge, 2004), Cambridge, UK.

Balmford, A., and T. Whitten. 2003. Who should pay for tropical conservation, and how could the costs be met? Oryx 37:238-250.

Bennett, E. L., and M. T. Gumal. 2001. The interrelationships of commercial logging, hunting and wildlife in Sarawak, and recommendations for forest management. Pages 359-374 in R. A. Fimbel, A. Grajal, and J. G. Robinson, editors. The cutting edge: conserving wildlife in logged tropical forest. Columbia University Press, New York, New York, USA. 
Bennett, E. L., A. J. Nyaoi, and J. Sompud. 1997. Hornbills Buceros spp. and culture in Northern Borneo: can they continue to coexist? Biological Conservation 82:41-46.

Bennett, E. L., A. J. Nyaoi, and J. Sompud. 2000. Saving Borneo's bacon: the sustainability of hunting in Sarawak and Sabah. Pages 305-324 in J. G. Robinson and E. L. Bennett, editors. Hunting for sustainability in tropical forests. Columbia University Press, New York, New York, USA.

Bernard, H. 2004. Effects of selective logging on microhabitat-use patterns of non-volant small mammals in a Bornean tropical lowland mixeddipterocarp forest. Nature and Human Activities 8:1-11.

BirdLife International. 2001. Threatened birds of Asia: the BirdLife International red data book. Birdlife International, Cambridge, UK.

Bowles, I. A., R. E. Rice, R. A. Mittermeier, and G. A. B. Dafonseca. 1998. Logging and tropical forest conservation. Science 280:1899-1900.

Brook, B. W., N. S. Sodhi, and P. K. L. Ng. 2003. Catastrophic extinctions follow deforestation in Singapore. Nature 424:420-423.

Bruner, A. G., R. E. Gullison, R. E. Rice, and G. A. B. da Fonseca. 2001. Effectiveness of parks in protecting tropical biodiversity. Science 291:125-128.

Colón, C. P. 1999. Ecology of the Malay Civet (Viverra tangalunga) in a logged and unlogged forest in Sabah, East Malaysia. Fordham University Press, Bronx, New York, USA.

Curran, L. M., S. N. Trigg, A. K. McDonald, D. Astiani, Y. M. Hardiono, P. Siregar, I. Caniago, and E. Kasischke. 2004. Lowland forest loss in protected areas of Indonesian Borneo. Science 303:1000-1003.

Fuller, D. O., T. C. Jessup, and A. Salim. 2003. Loss of forest cover in Kalimantan, Indonesia, since the 1997-1998 El Niño. Conservation Biology 18:249-254.

Grove, S. J. 2001. Extent and composition of dead wood in Australian lowland tropical rainforest with different management histories. Forest Ecology and Management 154:35-53.
Heydon, M. J., and P. Bulloh. 1997. Mousedeer densities in a tropical rainforest: the impact of selective logging. Journal of Applied Ecology 34:484-496.

Iskandar, D. T. 1999. Final report: training on "Monitoring Methods in Amphibians and Reptiles Fauna" at Soraya and Gunung Air Station, Leuser National Park. Institute of Technology, Bandung, Indonesia.

IUCN. 2003. IUCN red list of threatened species. Available online at: www.redlist.org/.

Jepson, P., J. K. Jarvie, K. MacKinnon, and K. A. Monk. 2001. The end for Indonesia's lowland forests? Science 292:859-861.

Jepson, P., F. Momberg, and H. van Noord. 2002. A review of efficacy of the protected area system of East Kalimantan Province. Natural Areas Journal 22:28-42.

Johns, A. D. 1983. Ecological effects of selective logging in a West Malaysian rainforest. University of Cambridge, Cambridge, UK.

Johns, A. D. 1989. Recovery of a peninsular Malaysian avifauna following selective timber logging: the first twelve years. Forktail 4:89-105.

Johns, A. G. 1996. Bird population persistence in Sabahan logging concessions. Biological Conservation 75:3-10.

Jordano, P.1983. Fig-seed predation and dispersal by birds. Biotropica 15:138-141.

Kingston, T., C. M. Francis, Z. Akbar, and T. H. Kunz. 2003. Species richness in an insectivorous bat assemblage from Malaysia. Journal of Tropical Ecology 19:67-79.

Kinnaird, M. F., T. G. O'Brien, and S. Suryadi. 1999. Importance of figs to Sulawesi's imperiled wildlife. Tropical Biodiversity 6:5-18.

Kramer, R., C. van Schaik, and J. Johnson, editors. 1997. Last stand: protected areas and the defense of tropical biodiversity. Oxford University Press, New York, New York, USA.

Lambert, F. R. 1989a. Fig eating birds in a Malaysian lowland rainforest. Journal of Tropical 
Ecology 5:401-412.

Lambert, F. R. 1989b. Daily ranging behaviour of three tropical frugivores. Forktail 4:107-116.

Lambert, F. R. $1989 c$. Fig-eating and seed dispersal by pigeons in a Malaysian lowland forest. Ibis 131:512-527.

Lambert, F. R. 1990. Some notes on fig-eating by arboreal mammals in Malaysia. Primates 31:453-458.

Lambert, F. R. 1991. The conservation of figeating birds in Malaysia. Biological Conservation 58:31-40.

Lambert, F. R. 1992. The consequences of selective logging for Bornean lowland forest birds. Philosophical Transactions of the Royal Society, London B 335:443-457.

Lambert, F. R., and N. J. Collar. 2002. The future for Sundaic lowland forest birds: long-term effects of commercial logging and fragmentation. Forktail 18:127-146.

Lammertink, M. 2004a. Grouping and cooperative breeding in the Great Slaty Woodpecker. Condor 106:309-319.

Lammertink, M. 2004b. A multiple-site comparison of woodpecker communities in Bornean lowland and hill forests. Conservation Biology 18:746-757.

Leighton, M., and D. R. Leighton. 1983. Vertebrates responses to fruiting seasonality within a Bornean rain forest. Pages 181-196 in S. L. Sutton, T. C. Whitmore, and A. C. Chadwick, editors. Tropical rain forest: ecology and management. Second edition. Blackwell Scientific, Oxford, UK.

Lugo, A. E. 1999. Will concern for biodiversity spell doom to tropical forest management? Science of the Total Environment 240:123-131.

Marshall, A. J., Nardiyono, L. M. Engström, B. Pamungkas, J. Palapa, E. Meijaard, and S. A. Stanley. 2006. The blowgun is mightier than the chainsaw in determining population density of Bornean orangutans (Pongo pygmaeus morio) in the forests of East Kalimantan. Biological Conservation 129:566-578.
Martin-Smith, K. M. 1998. Effects of disturbance caused by selective timber extraction on fish communities in Sabah, Malaysia. Environmental Biology of Fishes 53:155-167.

Meijaard, E. 1999. Human-imposed threats to sun bears in Borneo. Ursus 11:185-192.

Meijaard, E., D. Sheil, B. Rosenbaum, D. Iskandar, D. Augeri, T. Setyawati, W. Duckworth, M. J. Lammertink, I. Rachmatika, R. Nasi, A. Wong, T. Soehartono, S. Stanley, and T. O'Brien. 2005. Life after logging: reconciling wildlife conservation and production forestry in Indonesian Borneo. CIFOR, WCS and UNESCO, Bogor, Indonesia.

Ministry of Forestry. 1990. Act of the Republic of Indonesia No. 5 of 1990 concerning conservation of living resources and their ecosystems. Ministry of Forestry of the Republic of Indonesia, Jakarta, Indonesia.

Nijman, V. 2004. Habitat segregation in two congeneric hawk-eagles (Spizaetus bartelsi and $S$. cirrhatus) in Java, Indonesia. Journal of Tropical Ecology 20:105-111.

Nijman, V. 2005. Decline of the endemic Hose's langur Presbytis hosei in Kayan Mentarang National Park, East Borneo. Oryx 39:223-226.

Noerdjito, M., and I. Maryanto. 2001. Jenis-jenis hayati yang dilindungi perundang-undangan Indonesia. Balitbang Zoologi, Museum Zoologicum Bogoriense, Puslitbang LIPI, and The Nature Conservancy, Cibinong, Indonesia.

Noss, A. J., E. Cuellar, and R. L. Cuellar. 2004. An evaluation of hunter self-monitoring in the Bolivian Chaco. Human Ecology 32:685-702.

O'Brien, T. G. 1998. What's so special about figs? Nature 392:128.

O'Brien, T. G., M. F. Kinnaird, E. S. Dierenfeld, N. L. Conklinbrittain, R. W. Wrangham, and S. C.Silver. 1998. What's so special about figs? Nature 392:668.

Puri, R. K. 1994. A deadly dance of deception: Hunting knowledge of the Penan Benalui of East Kalimantan, Indonesia. Third Biennial International 
Conference of the Borneo Research Council (Pontianak, 1994). Borneo Research Council, Pontianak, West-Kalimantan, Indonesia.

Puri, R. K. 1997. Hunting knowledge of the Penan Benalui of East Kalimantan, Indonesia. Department of Anthropology, University of Hawaii, Honolulu, Hawaii, USA.

Puri, R. K. 2001. Bulungan ethnobiology handbook. A field manual for biological and social science research on the knowledge and use of plants and animals among 18 indigenous groups in northern East Kalimantan. Center for International Forestry Research, Bogor, Indonesia.

Putz, F. E., K. H. Redford, R. Fimbel, J. G. Robinson, and G. M. Blate. 2000. Biodiversity conservation in the context of tropical forest management. Wildlife Conservation Society and World Bank Environment Department, Biodiversity Series, Impact Studies, Paper Number 75. World Bank, Washington, D.C., USA.

Rachmatika, I., R. Nasi, and D. Sheil. 2004. Fish fauna in Bulungan Research Forest (BRF), Malinau, East Kalimantan. Center for International Forest Research, Bogor, Indonesia.

Rijksen, H. D., and E. Meijaard. 1999. Our vanishing relative: the status of wild orang-utans at the close of the twentieth century. Kluwer Academic, Dordrecht, The Netherlands.

Rodriguez, J. P., and K. M. Rodriguez-Clark. 2001. Even 'paper parks' are important. Trends in Ecology and Evolution 16:17.

Sheil, D., and E. Meijaard. 2005. Seeking life after logging: reconciling wildlife conservation and production forestry in Indonesian Borneo. Tropical Forest Update 15:12-15.

Sheil, D., R. Nasi, and B. Johnson. 2004. Ecological criteria and indicators for tropical forest landscapes: challenges in the search for progress. Ecology and Society 9(1):7. [online] URL: http://w ww.ecologyandsociety.org/vol9/iss1/art7/.

Sheil, D., R. K. Puri, I. Basuki, M. van Heist, Syaefuddin, Rukmiyati, M. A. Sardjono, I. Samsoedin, K. Sidiyasa, Chrisandini, E. Permana, E. M. Angi, F. Gatzweiler, and A. Wijaya. 2002. Exploring biological diversity, environment and local people's perspectives in forest landscapes. Report written with help from the people of Paya Seturan, Long Lake, Rian, Langap, Laban Nyarit, Long Jalan, Lio Mutai and Gong Solok. Center for International Forestry Research (CIFOR) with ITTO, Bogor, Indonesia.

Sist, P. 2001. Why RIL won't work by minimumdiameter cutting alone. ITTO Newsletter 11.

Sist, P., D. Sheil, K. Kartawinata, and H. Priyadi. 2003a. Reduced-impact logging in Indonesian Borneo: some results confirming the need for new silvicultural prescriptions. Forest Ecology and Management 179:415-427.

Sist, P., R. Fimbel, D. Sheil, R. Nasi, and M. H. Chevallier. 2003b. Towards sustainable management of mixed dipterocarp forests of South-east Asia: moving beyond minimum diameter cutting limits. Environmental Conservation 30:364-374.

Styring, A. P., and K. Ickes. 2003. Woodpeckers (Picidae) at Pasoh: foraging ecology, flocking and the impacts of logging on abundance and diversity. Pages 547-557 in T. Okuda, N. Manokaran, Y. Matsumoto, K. Niiyama, S. C. Thomas, and P. S. Ashton, editors. Pasoh: ecology of a lowland rain forest in Southeast Asia. Springer, Tokyo, Japan.

Styring, A. R.2002. Effects of selective logging on a guild of 13 syntopic woodpecker species in a Malaysian forest reserve. Pages 165-171 in $\mathrm{P}$. Pechacek and W. d'Oleire-Oltmanns, editors. International Woodpecker Symposium (Berchtesgarden, 2001). Forschungsbericht 48. Nationalparkverwaltung, Berchtesgaden, Germany.

Wadley, R. L., C. J. P. Colfer, and I. G. Hood. 1997. Hunting primates and managing forests - the case of Iban forest farmers in Indonesian Borneo. Human Ecology 25:243-271.

Wong, A. 2006a. The impact of forestry practices on frog communities in Sabah, Malaysia. Dissertation. Universiti Putra Malaysia, Kota Kinabalu, Malaysia, in press.

Wong, A. 2006b. Species diversity and abundance of frogs in different forestry practices in Sabah, Malaysia. In International Conference on Bornean Herpetology (Kota Kinabalu, 2003). Universiti Malaysia Sabah, Kota Kinabalu, Malaysia, in press. 
Zakaria, B. H. M. 1994. Ecological effects of selective logging in lowland dipterocarp forest on avifauna, with special reference to frugivorous birds. Universiti Kebangsaan, Kuala Lumpur, Malaysia. 